\title{
OPTIMALISASI PENERAPAN KURIKULUM 2013
}

\author{
Ahmad Arifai \\ Sekolah Tinggi Ilmu Tarbiyah Raudhatul Ulum Sakatiga \\ Email: sugrhu@gmail.com
}

\begin{abstract}
Abstrak
Berhasil tidaknya suatu pendidikan, mampu tidaknya seorang peserta didik dan pendidik dalam menyerap dan memberikan pengajaran, dan sukses tidaknya suatu tujuan pendidikan itu dicapai tentu akan sangat berpulang kepada kurikulum. Bila kurikulumnya didesain dengan teratur menurut sistem dan benar serta lengkap dengan segala kebutuhan pengembangan dan pembelajaran peserta didik untuk mempersiapkan diri menghadapi kehidupannya, tentu hasil pendidikan itupun akan mampu mewujudkan harapan, tapi bila tidak, kegagalan demi kegalan akan terus membayangi dunia pendidikan. Dalam menerapkan kurikulum 2013 yang masih dikatakan baru, karena semua pihak pengajar atau pendidik harus pintar-pintar melakukan pembaharuan baik itu dari skill pendidik itu sendiri maupun dari peserta didiknya. Untuk memberikan hasil yang diinginkan dalam kurikulum 2013 setidaknya ada upaya yang dilakukan oleh guru.

Upaya ini merupakan suatu usaha untuk menghasilkan kurikulum yang diterapkan secara maksimal. Dalam upaya yang dilakukan dapat dikatagorikan menjadi dua yaitu usaha yang ditujukan untuk peningkatan kualitas pendidikan dan untuk meningkatkan kualitas peserta didik. Adapun usaha yang di tujukan untuk mengoptimalisasikan pendidik adalah: 1) Meningkatkan mutu guru dengan cara memberikan pelatihan-pelatihan khusus tentang pendidikan. 2) Menyediakan sarana dan prasarana yang memadai, guna tercapainya tujuan pembelajaran yang maksimal. 3) Musyawarah setiap guru mata pelajaran. 4) Kepala sekolah dan guru bisa menerapkan dan Membudayakan penerapan kurikulum baru dalam meningkatkan mutu pendidikan pada sekolah tersebut. 5) Memberikan sertifikasi bagi guru berprestasi dalam meningkatkan mutu pendidikan di sekolahnya.
\end{abstract}

Kata Kunci: Optimalisasi, Penerapan Kurikulum 2013

\section{Pendahuluan}

Pendidikan adalah kebutuhan mutlak yang harus dipenuhi sepanjang hayat. Tanpa pendidikan, manusia tidak dapat berkembang dan menemukan kemampuannya sendiri, maka dari pada itu perkembangan dan kemampuan tidak lepas dari pendidikan. Pendidikan bukan saja dilakukan secara formal, tetapi dapat juga dilakukan melalui pendidikan non formal maupun secara informal.

Undang-Undang Dasar Republik Indonesia Tahun 1945 Pasal 31 Ayat (3) menegaskan bahwa pemerintah mengusahakan dan menyelenggarakan suatu sistem pendidikan nasional yag meningkatkan keimanan dan ketakwaan serta akhlak mulia dalam mencerdaskan kehidupan bangsa yang diatur undang-undang. Dan diperjelas lagi dalam Undang-Undang Repuplik Indonesia Pasal 20 Ayat (1) Tahun 2003 menyebutkan bahwa, pendidikan adalah usaha sadar dan terencana untuk 


\section{Optimalisasi Penerapan Kurikulum 2013}

Ahmad Arifai

mewujudkan suasana belajar dan proses pembelajaran agar peserta didik secara aktif mengembangkan potensi dirinya untuk memiliki kekuatan spiritual keagamaan, pengendalian diri, kepribadian, kecerdasan, akhlak mulia, serta keterampilan yang diperlukan dirinya, masyarakat, bangsa dan Negara.

Untuk mencapai tujuan tersebut bukanlah menjadi persoalan mudah bagi pendidikan Indonesia, di balik perjalanan pendidikan di Indonesia kritik yang menonjol adalah bahwa pendidikan kita cukup lama terlalu menekankan segi emosi, sosialitas, spiritualitas, kepribadian dan tanggung jawab kurang mendapat tekanan yang kuat, dan dari segi kognitifpun hasilnya belum tinggi karena hanya menekankan pada segi hapalan. Sekarang para pendidik lebih sadar bahwa pendidikan itu harus menyeluruh yaitu mengembangkan semua aspek dan kehidupan manusia. Maka kecuali dalam segi pengetahuan, perihal yang dikembangkan adalah seperti emosi, rohani, spiritual, sosial, kepribadian, kemasyarakatan dan tanggung jawab.

Pada sisi lain, upaya sentralnya berporos pada pembaharuan kurikulum pendidikan. Sebagai usaha terencana, pembaharuan kurikulum tentulah didasari oleh alasan yang jelas dan substantif serta mengarah pada terwujudnya sosok kurikulum yang lebih baik, dalam arti yang seluas-luasnya, bukan sekadar demi perubahan itu sendiri. Artinya, pembaharuan kurikulum selayaknya diabadikan pada terwujudnya praktik pembelajaran yang berkualitas. Baik dalam kaitanya dengan studi lanjut, memasuki dunia kerja, maupun belajar mandiri. Maka dari itu pemerintah mengambil kebijakan-kebijakan terhadap perubahan kurikulum di Indonesia.

\section{Pembahasan}

\section{a. Kurikulum dan Pendidikan}

Kurikulum dan pendidikan merupakan dua konsep dasar yang saling berhubungan seperti magnet dan bahan logam, antara yang satu dengan yang lainnya saling berhubungan dan tak bisa dipisahkan. Kurikulum merupakan pedoman mendasar dalam proses belajar mengajar di dunia pendidikan.

Berhasil tidaknya suatu pendidikan, mampu tidaknya seorang peserta didik dan pendidik dalam menyerap dan memberikan pengajaran, dan sukses tidaknya suatu tujuan pendidikan itu dicapai tentu akan sangat berpulang kepada kurikulum. Bila kurikulumnya didesain dengan teratur menurut sistem dan benar serta lengkap dengan segala kebutuhan pengembangan dan pembelajaran peserta didik untuk mempersiapkan diri menghadapi kehidupannya, tentu hasil pendidikan itupun akan mampu mewujudkan harapan, tapi bila tidak, kegagalan demi kegalan akan terus membayangi dunia pendidikan.

Hasbullah mengatakan di dalam bukunya berjudul Dasar-dasar Ilmu Pendidikan, Pendidikan adalah usaha manusia untuk membina kepribadiannya sesuai dengan nilai-nilai dalam masyarakat dan kebudayaan.(Hasbullah, 2008:1) Sedangkan menurut Fuad Ihsan di dalam bukunya yang berjudul Dasar-dasar 
Volume 2 Nomor 1 Edisi Juni 2017

P-ISSN : 2541-3686

Kependidikan, Pendidikan adalah usaha manusia untuk menumbuhkan dan mengembangkan potensi-potensi pembawaan baik jasmani maupun rohani sesuai dengan nilai-nilai yang ada di dalam masyarakat dan kebudayaan. (Fuad Ihsan, 1996:2) Jadi bisa disimpulkan bahwa pendidikan adalah suatu kegiatan manusia untuk mendapatkan dan mengembangkan nili-nilai dan potensi-potensi yang ada pada dirinya baik secara jasmani maupun rohani dengan harapan agar bisa bersaing dengan masyarakat dan kebudayaan secara global.

Sedangkan kurikulum menurut Hamalik, kurikulum adalah semua kegiatan dan pengalaman yang menjadi tanggung jawab sekolah, baik yang dilaksanakan di lingkungan sekolah maupun di luar sekolah dalam rangka mencapai tujuan pendidikan. (Oemar Hamalik, 1995:15) Sedangkan menurut Subandja bahwa kurikulum adalah aktivitas dan kegiatan belajar yang direncanakan dan diprogramkan bagi peserta didik di bawah bimbingan sekolah, di kelas, maupun di luar sekolah.(Subandja, 1993:2) Dan pada zaman dahulu orang mengatakan bahwa kurikulum merupakan suatu mata pelajaran untuk mencapai suatu kompetensi tertentu.

Kompetensi merupakan perpaduan dari pengetahuan, keterampilan, nilai dan sikap yang direfleksikan dalam kebiasaan berpikir dan bertindak. Dalam hal ini kompetensi diartikan sebagai pengetahuan, keterampilan, dan kemampuan yang dikuasai oleh seseorang yang telah menjadi bagian dari dirinya, sehingga ia dapat melakukan perilaku-perilaku kognitif, afektif, dan psikomotorik dengan sebaikbaiknya.( E.Mulyasa, 2006:38) Sedangkan Karakter merupakan sifat khas yang dimiliki oleh individu yang membedakannya dari induvidu lain, atau suatu kepribadian yang memiliki ciri khas. (A.Kamarulzaman, 2005:319)

Kebijakan perubahan kurikulum lama menjadi kurikulum baru merupakan suatu politik pendidikan yang mana seakan setiap pergantian pemerintahan berganti pula kebijakan pendidikan. Kebijakan pendidikan ini seperti yang dikatakan oleh Menteri Pendidikan dan Kebudayaan Republik Indonesia Muhammad Nuh mengatakan perubahan dan pengembangan kurikulum merupakan persoalan penting dan genting demi terciptanya mutu pendidikan yang lebih baik lagi dan bisa bersaing dengan Negara Luar yang lebih maju dalam dunia pendidikannya.

Perubahan kurikulum lama KTSP menjadi kurikulum 2013 sudah dilakukan pemerintah sesuai dengan standardisasi dan profesionalisasi pendidikan, seperti di tuangkan dalam Peraturan Pemerintah Nomor 19 Tahun 2005 tentang Standar Nasional Pendidikan (SNP), yang telah di sempurnakan dalam peraturan pemerintah No.32 Tahun 2013.

Kurikulum 2013 adalah kurikulum yang berbasis kompetensi dan karakter yang mengedepankan tiga konsep mendasar yaitu:

Konsep yang pertama, kurikulum sebagai substansi. Kurikulum sebagai suatu rencana kegiatan belajar bagi siswa-siswa di sekolah, atau sebagai perangkat tujuan yang ingin dicapai. Suatu kurikulum juga dapat menunjuk kepada suatu dokumen 
yang berisi rumusan tentang tujuan, bahan ajar, kegiatan belajar mengajar, jadwal dan evaluasi.

Konsep yang kedua, kurikulum 2013 sebagai sistem, yaitu sistem kurikulum. Sistem kurikulum merupakan bagian dari sistem sekolahan, sistem pendidikan, bahkan sistem masyarakat.

Konsep yang ketiga, kurikulum 2013 sebagai bidang studi kurikulum. Ini merupakan bidang kajian para ahli kurikulum dan ahli pendidikan dan pengajaran. Tujuan kurikulum sebagai bidang studi adalah mengembangkan ilmu tentang kurikulum dan sistem kurikulum.

\section{b. Pengertian Penerapan Kurikulum}

Penerapan berasal dari kata terap yang dapat imbuhan dari pe-an yang artinya proses, cara, pembuatan, menerapkan atau mempraktekkan.(KBBI, 2001:180) Penerapan bukan sekadar aktivitas, tetapi suatu kegiatan yang terencana dan dilakukan secara bersungguh-sungguh bedasarkan acuan norma tertentu untuk mencapai tujuan kegiatan. Oleh karena itu penerapan disini tidak berdiri sendiri, tetapi dipengaruhi oleh objek berikutnya yaitu kurikulum sebagaimana sudah dijelaskan pada sebelumnya.

Sedangkan kurikulum, Kurikulum berasal dari bahasa yunani, yaitu dari kata currir artinya pelari, kata curere artinya tempat berpacu. Jadi kurikulum diartikan jarak yang ditempuh oleh seorang pelari pada saat itu. Pada dunia pendidikan kurikulum diartikan sejumlah mata pelajaran yang harus ditempuh oleh peserta didik untuk mencapai suatu gelar atau ijazah.

Sedangkan kurikulum menurut Hamalik, kurikulum adalah semua kegiatan dan pengalaman yang menjadi tanggung jawab sekolah, baik yang dilaksanakan di lingkungan sekolah maupun di luar sekolah dalam rangka mencapai tujuan pendidikan. (Oemar Hamalik, 1995:15) Lain lagi menurut Subandja bahwa kurikulum adalah aktivitas dan kegiatan belajar yang direncanakan dan diprogramkan bagi peserta didik di bawah bimbingan sekolah, di kelas, maupun di luar sekolah.

Maka, pengertian penerapan kurikulum adalah suatu rencana atau kegiatan yang diterapkan dan dilaksanakan oleh sekolah untuk mencapai tujuan pandidikan yang diharapkan bisa menjadikan peserta didik yang cerdas baik itu secara ilmu, keterampilan maupun akhlak yang baik, melalui setiap pelajaran dan pendidikan yang ada di sekolah.

1. Pengertian Kurikulum Tingkat Satuan Pendidikan (KTSP)

Kurikulum Tingkat Satuan Pendidikan adalah kurikulum operasional yang disusun, dikembangkan, dan dilaksanakan oleh setiap satuan pendidikan dengan memperhatikan standar kompetensi. Kompetensi dasar yang dikembangkan Badan Standar Nasional Pendidikan (BSNP). Konsep dasar KTSP dalam standar nasional pendidikan (SNP) Pasal 1, ayat (15) dikemukakan bahwa Kurikulum Tingkat Satuan Pendidikan (KTSP) adalah kurikulum operasional yang disusun dan dilaksanakan 
Volume 2 Nomor 1 Edisi Juni 2017

P-ISSN : 2541-3686

oleh masing-masing satuan pendidikan. Penyusunan KTSP dilakukan oleh satuan pendidikan dengan memperhatikan dan berdasarkan standar kompetensi serta kompetensi dasar yang dikembangkan oleh Badan Standar Nasional Pendidikan (BSNP). KTSP disusun dan dikembangkan berdasarkan Undang-Undang Nomor 20 Tahun 2003 tentang Sistem Pendidikan Nasional pasal 36 ayat (1) bahwa: pengembangan kurikulum dilakukan dengan mengacu pada standar nasional pendidikan untuk mewujudkan tujuan pendidikan nasional. Ayat (2) menyatakan bahwa: Kurikulum pada semua jenjang dan jenis pendidikan dikembangkan dengan prinsip diversifikasi sesuai dengan satuan pendidikan, potensi daerah, dan peserta didik. (E. Mulyasa, 2007:20).

\section{Pengertian Kurikulum 2013}

Kurikulum 2013 adalah seperangkat rencana mengenai tujuan dan isi bahan pelajaran yang lebih menekankan agar melahirkan generasi penerus bangsa yang produktif, kreatif, inovatif, dan berkarakter serta merealisasikan pendidikan nasional untuk membentuk watak dan peradaban bangsa yang bermartabat.

Kurikulum harus disusun dan disempurnakan sesuai dengan perkembangan zaman. Oleh karena itu, seiring dengan perkembangan zaman pendidikan semakin banyak menghadapi tantangan-tantangan diera globalisasi saat ini. Sebagaimana filosofi kurikulum 2013 versi Sisdiknas, Undang-Undang Sisdiknas Pasal 1 Butir 1 dan 2 : Hakikat pendidikan adalah peserta didik secara aktif mengembangkan potensi dirinya untuk memiliki kompetensi yang berakar pada nilai-nilai agama, kebudayaan nasional Indonesia dan tanggap terhadap tuntutan perubahan zaman.

Kurikulum 2013 juga berpegang teguh pada filosofi al-Qur'an QS. al-a'alaq ayat 1-5 yang artinya:

1. Bacalah dengan (menyebut) nama Tuhanmu yang menciptakan,

2. Dia telah menciptakan manusia dari segumpal darah,

3. Bacalah, dan Tuhanmulah yang Maha Pemurah,

4. Yang mengajar (manusia) dengan perantara kalam,

5. Dia mengajar kepada manusia apa yang tidak di ketahuinya.

Kurikulum 2013 merupakan kurikulum yang berdasarkan hasil dari tindak lanjut dari Kurikulum Berbasis Kompetensi (KBK) yang pernah dijalankan pada tahun 2004 sampai pertengahan 2006, barulah setelah kurikulum yang ada di Indonesia mengalami perubahan lagi dengan alasan untuk penyempurnaan dari kurikulum yang berbasis kompetensi. KBK 2004 dijadikan acuan bagi pelaksanaan pendidikan untuk mengembangkan berbagai rana pendidikan yaitu pengetahuan, keterampilan dan sikap dalam seluruh jenjang pendidikan.

Seiring pergantian kurikulum tingkat satuan pendidikan (KTSP) menjadi kurikulum 2013 ini maka menurut Muhammad Nuh sebagai Menteri Pendidikan menegaskan bahwa kurikulum 2013 dirancang sebagai upaya untuk menyiapkan generasi Indonesia 2045 yaitu tepatnya seratus tahun Indonesia merdeka, sekaligus memanfaatkan populasi usia yang produktif yang jumlahnya sangat banyak agar 
menjadi manusia-manusia yang memiliki kemampuan dan karakter yang kuat dan bisa bersanding dengan bangsa-bangsa lainnya dan tidak semakin terpuruk.

\section{a. Optimalisasi Penerapan Pada Kurikulum 2013}

Dalam menerapkan kurikulum 2013 yang masih dikatakan baru, karena semua pihak pengajar atau pendidik harus pintar-pintar melakukan pembaharuan baik itu dari skill pendidik itu sendiri maupun dari peserta didiknya. Untuk memberikan hasil yang diinginkan dalam kurikulum 2013 setidaknya ada upaya yang dilakukan oleh guru.

Upaya ini merupakan suatu usaha untuk menghasilkan kurikulum yang diterapkan secara maksimal. Dalam upaya yang dilakukan dapat dikatagorikan menjadi dua yaitu usaha yang ditujukan untuk peningkatan kualitas pendidikan dan untuk meningkatkan kualitas peserta didik.

Adapun usaha yang di tujukan untuk mengoptimalisasikan pendidik adalah:

1) Meningkatkan mutu guru dengan cara memberikan pelatihan-pelatihan khusus tentang pendidikan, dengan harapan menciptakan guru yang berkulitas dan profesional,

2) Menyediakan sarana dan prasarana yang memadai, guna tercapainya tujuan pembelajaran yang maksimal,

3) Musyawarah setiap guru mata pelajaran, dengan tujuan musyawarah ini adalah menyatukan pandangan guru terhadap konsep umum pendidikan dan fungsi sekolah dalam pencapaian tujuan pendidikan, selain itu untuk menyatukan pendapat terhadap metode-metode yang akan di gunakan dalam proses belajar mengajar serta pemecahan segala permasalahan yang ada dalam pengajaran,

4) Kepala sekolah dan guru bisa menerapkan dan Membudayakan penerapan kurikulum baru dalam meningkatkan mutu pendidikan pada sekolah tersebut,

5) Memberikan sertifikasi bagi guru berprestasi dalam meningkatkan mutu pendidikan di sekolahnya.

Adapun upaya optimalisasi untuk kemajuan peserta didik menurut di dalam buku E. Ramayulis tentang pengembangan dan implementasi kurikulum 2013 adalah: mendongrak prestasi, penghargaan dan hadiah, membangun tim, program akselarasi, mengimplementasikan kurikulum melalui budaya, melibatkan masyarakat, menghemat biaya pendidikan, dan membangun jiwa kewirausahaan.

Dalam mengoptimalisasikan kurikulum 2013 ini tidak sepenuhnya berjalan sesuai dengan harapan, ada kesulitan sebagian guru dalam mengoptimalisasikan kurikulum baru ini misalnya keterbatasan fasilitas mengajar, keterlambatan pengiriman buku tematik dari departemen pendidikan dan kebudayaan, dan kurangnya pemahaman guru atas arah dan tujuan kurikulum itu sendiri.

\section{b. Kriteria Keberhasilan pada Kurikulum 2013}


Volume 2 Nomor 1 Edisi Juni 2017

P-ISSN : 2541-3686

Keberhasilan penerapan kurikulum 2013 dalam pembentukan kompetensi dan karakter peserta didik dapat dilihat dari segi proses dan dari segi hasil. Dari segi proses, pembentukan kompetensi dan karakter dikatakan berhasil dan berkualitas apabila setidaknya sebagian besar peserta didik terlibat aktif, baik itu secara fisik, mental maupun sosial. ketika dalam proses belajar, minat belajar anak yang tinggi, bersosial yang baik, semangat, dan memiliki rasa percaya pada diri sendiri.

Sedangkan dari segi hasil, proses pembentukan dan karakter dikatakan berhasil apabila terjadi perubahan prilaku yang positif pada peserta didik, masukan pembelajaran kurikulumnya berjalan dengan baik tanpa setengah-setengah dan menghasilkan output yang banyak dan bermutu sesuai dengan kebutuhan, perkembangan dan pembangunan dalam bermasyarakat.

Keberhasilan pembelajaran dalam penerapan kurikulum baru ini, mengandung makna ketuntasan dalam belajar dan ketuntasan dalam proses pembelajaran. Tercapainya kompetensi seperti pengetahuan, keterampilan, dan sikap. Secara umum kriteria keberhasilan pembelajaran adalah: pertama, keberhasilan peserta didik menyelesaikan serangkaian tes, baik tes formatif, tes sumatif, maupun tes keterampilan. Kedua, setiap keberhasilan dihubungkan dengan standar kompetensi dan kompetensi dasar yang mengacu kepada kriteria ketuntasan minimal (KKM), atau kriteria ketuntasan ideal (KKI), dan ketiga adalah ketercapaian keterampilan vokasional atau praktik bergantung pada KKM atau KKI. Sedangkan indikator adalah acuan untuk menentukan apakah peserta didik telah berhasil menguasai kompetensi.

Untuk memenuhi tuntutan tersebut perlu dikembangkan pengalaman belajar yang kondusif untuk membentuk manusia yang berkualitas tinggi, baik mental, moral maupun fisik. Pengalaman belajar tersebut bisa dilihat dari ketekunan peserta didik dalam proses belajar, waktu untuk belajar. Peserta didik memerlukan waktu yang cukup untuk menguasai sesuatu yang dipelajari, kadar pembelajaran untuk setiap peserta didik yang berlainan dan juga bergantung pada sikap, mutu penyampaian guru dan usahanya memahami sesuatu pembelajaran, mutu kegiatan pembelajaran, penyampaian guru yang menarik sangat perlu untuk memudahkan peserta didik menguasai suatu pelajaran.

Di dalam penerapan kurikulum 2013 ini, menurut E. Ramayulis dalam bukunya yang berjudul Pengembangan dan Implementasi Kurikulum 2013, keberhasilan implementasi kurikulum 2013 berbasis kompetensi dan karakter dapat dilihat dalam jangka pendek, jangka menengah dan jangka panjang dengan kriteria sebagai berikut:

1) Kriteria jangka pendek, sekurang-kurangnya $75 \%$ peserta didik memahami materi di dalam penerapan pada kurikulum 2013 ialah dengan cara menerima, menerapkan, memahami materi dan mengembangkan dari proses hasil yang diajarkan oleh guru, 
2) Kriteria jangka menengah, peserta didik diharapkan menerima umpan balik tehadap guru, menjadi kreatif dan peserta didik tidak memberikan pengaruh negatif terhadap masyarakat lingkungan dengan cara apapun,

3) Kriteria jangka panjang, meningkatnya mutu pendidikan, efisiensi, efektivitas dan peningkatan perhatian, partisipasi tanggung jawab, dan kompetisi yang sehat antar sekolah, kemandirian, menjadikan sekolah yang aman, nyaman, tertib, dan evaluasi bersama secara berkelanjutan.

\section{Simpulan}

Untuk mewujudkan penerapan kurikulum 2013 secara optimal bukanlah hal yang mudah, maka seyogyanya segala upaya yang berkaitan dengan tujuan untuk memajukan kualitas atau mutu pendidikan tidak lepas dari peran guru, apabila guru-gurunya berkualitas dan inovatif maka penerapan kurikulum 2013 ini dipastikan berhasil, karena kurikulum 2013 ini menuntut seorang guru lebih kreatif dan cerdas serta mampu menguasai lebih dari satu kemampuan yang dimilikinya.

Satu hal yang mendasar digantinya kurikulum tingkat satuan pendidikan menjadi kurikulum 2013 ini dikarenakan tingkat satuan pendidikan telah gagal menciptakan nilai-nilai karakter terhadap peserta didik seperti merosotnya prestasi pendidikan, merosotnya nilai kejujuran di dalam pelaksanaan ujian akhir nasional, keamanan masyarakat sering terjadi beberapa tahun terakhir ini contoh yang paling nyata tawuran antar sekolah, prilaku sadisme, serta gagal menjaga persatuan dan kesatuan bangsa yang bisa dilihat dari kurangnya rasa simpati, toleransi pada sesamanya sendiri. Dan semua itu berpengaruh buruk terhadap pendidikan dan perkembangan sumber daya manusia. Oleh karena itu, pendidik perlu menyadari bahwa belakangan ini dunia pendidikan telah dihadapkan pemandangan baru, yang mana dunia pendidikan kita telah digrogoti dengan kekerasan, lemahnya percaya diri peserta didik dalam menghadapi evaluasi nasional atau disebut Ujian Akhir Nasional, pengaruh alat teknologi yang disalah gunakan dan kurangnya rasa hormat terhadap orang tua dan guru. 
RAUDHAH Proud To Be Professionals qurnal Tarbiyak7damiyak

Volume 2 Nomor 1 Edisi Juni 2017

P-ISSN : 2541-3686

\section{DAFTAR PUSTAKA}

E. Mulyasa, Kurikulum Tingkat Satuan Pendidikan, Sebuah Panduan Praktis, Bandung: Rosdakarya, 2007

E.Mulyasa, Kurikulum Berbasis Kompotensi (Konsep, Karakteristik, Implementasi, dan Inovasi), Bandung: PT. Ramaja Rosdakarya, 2006

Departemen Pendidikan Nasional, Kamus Besar Bahasa Indonesia, Jakarta:Balai Pustaka, 2001

Aka Kamarulzaman dan M. Dahlan . Al Barry, Kamus Ilmu Serapan,Yogyakarta: Absolut, 2005

Hasbullah, Dasa-Dasar Ilmu Kependidikan, Jakarta:PT. Rajagranfindo Persada, 2008

Fuad Ihsan, Dasar-Dasar Kependidikan, Jakarta: PT.rineka Cipta, 1996

Oemar Hamalik, Pengembangan Kurikulum Lembaga Pendidikan dan Pelatihan, Bandung: Trigenda Karya, 1995

Subandja, Pengembangan dan Inovasi Kurikulum, Jakarta: Grafindo, 1993 
Optimalisasi Penerapan Kurikulum 2013

Ahmad Arifai 